\title{
PRAKTIK PESAN MAKANAN MELALUI GO-FOOD DI KOTA SURABAYA PERSPEKTIF HUKUM ISLAM
}

\author{
Mohammad Nuruddin \\ Surabaya \\ nowroaddieand@gmail.com
}

\begin{abstract}
This study focuses on the problem of the practice of ordering food through Go-Food services on the Go-Jek application in Surabaya and the analysis of Islamic law. This type of research is a field research by using a qualitative descriptive research approach to describe the conditions, situations, or phenomena about the data obtained, namely about the practice of ordering food through Go-food services on the Go-Jek application in the city of Surabaya. Then, it is analyzed by using a deductive mindset, namely by explaining in advance about various things regarding the theory of ijarah, wakalah and the theory of buying and selling. The results of the study concluded that the application of the food ordering system through Go-Food on the Go-Jek application from the pillars and conditions that use this ijarah contract is fully appropriate and valid according to Islamic law. From the conclusion above, the author gives suggestion to the Go-Jek application development party, especially on Go-Food services to provide a time limit for customers to cancel for certain reasons, precisely before the driver completes the purchase of customer food orders at the stall/ the destination restaurant. This is to reduce the losses that will be borne by the driver.
\end{abstract}

Keywords: Ijarah, Go-food, Wakalah, Buying and Selling

\begin{abstract}
Abstrak: Penelitian ini bertujuan untuk menjawab permasalahan praktik pemesanan makanan melalui jasa Go-Food pada aplikasi Go-Jek di Surabaya serta analisis hukum Islamnya. Jenis Penelitian adalah penelitian lapangan (Field research) dengan menggunakan pendekatan penelitian deskriptif kualitatif, yaitu menggambarkan kondisi, situasi, atau fenomena tentang data yang diperoleh, yaitu tentang praktik pemesanan makanan melalui jasa Go-food pada aplikasi Go-Jek di kota Surabaya. Kemudian dianalisis dengan menggunakan pola pikir deduktif, yakni dengan menjelaskan terlebih dahulu tentang berbagai hal mengenai teori ijarah, wakalah dan teori jual beli. Setelah menjelaskan tentang teori-teori tersebut akan dihubungkan dengan kenyataan-kenyataan yang terjadi di lapangan. Hasil penelitian menyimpulkan bahwa, penerapan sistem pemesanan makanan melalui Go-Food pada aplikasi Go-Jek dari rukun dan syaratnya yang menggunakan akad ijarah ini sepenuhnya telah sesuai dan sah menurut syariat Islam. Dari kesimpulan di atas, penulis memberikan saran kepada pihak pengembangan aplikasi Go-Jek, khususnya pada layanan jasa Go-Food untuk memberikan batas waktu pelanggan bisa melakukan canceling (pembatalan) dengan sebab tertentu, tepatnya sebelum pihak driver menyelesaikan pembelian pesanan makanan pelanggan di warung/restoran yang dituju, hal ini untuk mengurangi kerugian yang akan ditanggung oleh driver.
\end{abstract}

Kata Kunci: ijarah, Go-food, Wakalah, Jual Beli

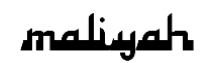

Jurnal Hukum Bisnis Islam

Volume 10, Nomor 01, Juni 2020

p-ISSN: 2088-4869/ e-ISSN: 2597-4351 


\section{Pendahuluan}

Umat Islam telah bersepakat bahwa Al-Qur'an merupakan dalil/ sumber utama hukum Islam. Selaku dalil/ sumber utama hukum Islam, Al-Qur'an telah menyajikan dasardasar pokok dan prinsip-prinsip umum hukum Islam. ${ }^{1} \mathrm{Al}-$ Qur'an dan As-Sunnah yang menjadi sumber dan pedoman bagi umat untuk bertindak mengandung ajaran-ajaran tentang akidah dan ajaran tentang syariah. Kemudian, syariah itu sendiri terdiri atas ibadah dan mu'amalah. ${ }^{2}$

Islam memiliki sifat komprehensif karena mencakup semua dimensi atau aspek kehidupan manusia baik yang ritual (mahdoh) maupun sosial (mu'amalah), material dan moral, ekonomi, politik, hukum, sosial, kebudayaan, keamanan, nasional, dan internasional. ${ }^{3} \mathrm{Di}$ dalam melakukan kegiatan sosial (mu'amalah), Islam memiliki prinsip-prinsip mu'amalah. Karya yang ditulis oleh Mardani, di dalam bukunya yang berjudul Fiqh Ekonomi Syariah menyebutkan bahwa terdapat sebelas prinsip-prinsip muamalah yaitu prinsip tauhydy (unity), prinsip halal, prinsip mașlaḥah, prinsip kebebasan berinteraksi, prinsip kerjasama, prinsip membayar zakat, prinsip keadilan, prinsip amanah, prinsip komitmen terhadap al-akhlaq alkarimah, dan prinsip terhindar dari jual beli dan investasi yang dilarang. ${ }^{4}$

Seiring berjalannya waktu, zaman semakin berkembang dalam segala aspek pendidikan dan ilmu pengetahuan. Terutama dalam ruang lingkup teknologi yang semakin canggih, contohnya dari surat menyurat melewati tukang pos

\footnotetext{
${ }^{1}$ Asnawi, Teori Maslahat Dan Relevansinya Dengan Perundang - Undangan Pidana Khusus Di Indonesia (Jakarta: Badan Litbang dan Diklat Kementrian Agama RI, 2010).1

${ }^{2}$ Mahmud Syaltut, Al-Islam 'Aqidah Wa Shari'Ah (Kuwait: Daar al-Qalam, 1966).11-13

${ }^{3}$ Ibid. 22

${ }^{4}$ Mardani, Fiqh Ekonomi Syariah (Jakarta: Kencana, 2013).7-12
} 
hingga telepon antar suara, dari mencuci di sungai hingga mencuci otomatis di mesin cuci, dari masak dengan kayu bakar hingga memasak menggunakan tenaga listrik.

Dari perkembangan teknologi banyak membuka peluang kerja bagi para pengangguran atau menjadi alternatif yang mudah bagi para pekerja di bidang jasa. Karena melalui telepon yang canggih yang disebut smartphone dengan didukung oleh sinyal internet akan mempermudah komunikasi. Sehingga promosi dan penawaran dalam jual beli menjadi semakin mudah bagi para penjual dan pembeli yang sering disebut jual beli online. Bahkan perbedaan jarak yang jauh pun tidak menjadi kendala lagi, sebab banyak yang menawarkan jasa kirim barang dari maraknya jual beli online tersebut. Tidak hanya jual beli barang saja yang bisa melalui online, namun penawaran berbagai jasa pun saat ini bisa melalui smartphone. Terdapat penawaran jasa kirim barang, jasa ojek, jasa pijat, jasa membersihkan rumah dan lain-lain.

Apabila pada smarthpone kita terdapat aplikasi playstore, maka kita akan menemukan banyak sekali aplikasi yang ditawarkan di dalamnya, sudah seperti pasar aplikasi yang canggih. Salah satu aplikasi di playstore yang populer dalam kategori jasa online adalah Go-Jek yang didesain oleh PT. Aplikasi Karya Anak Bangsa. Aplikasi Go-jek telah didownload lebih dari 10 Juta orang, aplikasi tersebut melayani kebutuhan dalam transportasi, delivery, pesan makanan, bayar tagihan dan pulsa. ${ }^{5}$

Usaha jasa yang ada dalam aplikasi Go-Jek termasuk usaha layanan jasa, sehingga ojek ini menggunakan akad ijärah. Ijärah telah diatur dalam Syar'iat Islam. Dalil Al-Qur'an yang menerangkan tentang ijärah yakni:

“..... Kemudian jika mereka menyusukan (anak-anak)mu untukmu, maka berikanlah kepada mereka upahnya dan musyawarahkanlah di antara kamu (segala sesuatu dengan baik). Dan jika kamu menemui kesulitan maka

${ }^{5}$ Ibid. 
perempuan lain menyusukan (anak itu) untuknya. (QS. At-Thalāq: 6). ${ }^{6}$

Dari sekian banyaknya kategori jasa yang ditawarkan oleh Go-Jek ada satu jasa yang menurut penulis patut mendapatkan perhatian, yakni jasa pesan makanan yang diberi nama Go-Food. Dalam praktiknya, Go-Food melayani jasa beli dan antar makanan yang dipesan oleh konsumen melalui aplikasi Go-jek yang tersedia di Smartphone. Konsumen tinggal memilih restaurant, kedai atau tempat makanan yang tertera didaftar pilihan Go-food.

Mengenai biaya jasa driver, maka akan muncul harga secara otomatis yang ditentukan sesuai jarak per-km antara pembeli/pemesan dengan jarak toko makanan/kedai yang dipilih tersebut. Apabila harga makanan dan harga biaya jasa driver telah muncul dan disetujui oleh pemesan, maka tinggal menekan tombol "pesan sekarang" maka pihak Driver Go-Jek terdekat yang melayani jasa Go-Food akan mendapatkan notifikasi di smartphone-nya dan akan menuju tempat makanan yang diinginkan konsumen dan membeli makanan yang diinginkan oleh pelanggan.

Cara pembayaran harga makanan dan harga biaya jasa Go-food saat ini bisa dengan dua cara, yakni dibayar melalui saldo uang yang dimiliki pelanggan pada dompet aplikasi Gojek yang diberi nama "Go-Pay" atau dengan cara membayar langsung pada driver jika dia telah tiba mengantarkan makanan yang telah dibeli dengan uang milik driver terlebih dahulu.

Namun tidak lepas dari resiko dari adanya pemesanan makanan secara online melalui jasa Go-food ini. Pertama, resiko bagi pembeli, diantaranya perubahan harga makanan dari pihak restoran, ketidaksesuaian makanan yang diterima dengan foto/gambar pada aplikasi, waktu tibanya driver yang tidak pasti dengan sebab tertentu, dan lain-lain. Kedua, resiko

\footnotetext{
${ }^{6}$ Departemen Agama RI, Al-Qur'an Dan Terjemahnya (Jakarta pusat: Pena, 2011).559
} 
bagi Driver diantaranya adalah respon pembeli apabila terjadi perubahan makanan yang tidak sesuai kesepakatan sebelumnya di aplikasi Go Food, pembatalan secara sepihak oleh pemesan dengan sebab tertentu bahkan dengan alasan yang tidak benar, driver membutuhkan antrian lama, biaya parkir motor di toko makanan dan lain-lain.

Pembayaran yang dilakukan di awal waktu ketika transaksi oleh pelanggan dengan menggunakan Go-Pay, nampak seperti menjual barang yang belum jelas/belum ada serah terima ketika saat itu. Perlu kita ingat, bahwa Rasulullah saw melarang untuk menjual barang yang belum menjadi milik atau tanggung jawabnya. Beliau juga melarang menjual makanan yang belum diserahterimakan (taqabudh). Dengan adanya larangan tersebut, dan melihat perkembangan bentuk perekonomian pada zaman ini, maka para ulama melakukan istinbat hukum, fatwa dan ijtihad dengan lahirnya kaidah alkharraj bi adh-Dhaman (keseimbangan antara keuntungan dan resiko) untuk menghadapi transaksi jual beli yang belum diserahterimakan. ${ }^{7}$

Melihat praktik yang terjadi diatas, jika ditinjau dari sisi Hukum Islam, apabila dalam transaksi pemesanan melalui jasa Go-food tersebut ditemukan suatu perubahan kondisi yang bisa memunculkan unsur ketidakjelasan (ghoror), maka akan mengakibatkan kerugian atau resiko bagi masing-masing pihak, yakni bagi pemesan atau bagi driver kita perlu melakukan penelitian agar mengetahui kebenaran dan keadilannya sesuai dengan aturan Hukum Islam.

Penelitian ini merupakan hasil penelitian lapangan atau field research dengan teknik pengumpulan data menggunakan wawancara dengan para driver dan konsumen. Kemudian data di olah dengan tahapan editing, organising dang analysing. Selanjutnya data tersebut di analysis menggunakan teknik pola pikir deskriptif deduktif yakni mendeskripsikan data yang

${ }^{7}$ Oni Sahroni and Dkk, Maqashid Bisnis Dan Keuangan Islam (Jakarta: Rajawali Press, 2015).80-81 
diperoleh dari lapangan terkait praktik pemesanan makanan melalui jasa go-food pada aplikasi go-jek di kota Surabaya.

\section{Ijārah, Jual Beli dan Wakalah}

\section{Pengertian Ijārah}

Salah satu bentuk kegiatan manusia dalam lingkup muamalah ialah sewa-menyewa yang dalam bahasa Arab diistilahkan dengan al- ijarah. ${ }^{8}$ Menurut bahasa, ijarah berarti "upah" atau "ganti" atau "imbalan". Karena itu kata ijarah mempunyai pengertian umum yang meliputi upah atas pemanfaatan suatu benda atau imbalan suatu kegiatan, atau upah karena melakukan sesuatu aktivitas. ${ }^{9}$

Secara istilah atau terminologi, ijarah terdapat banyak definisi yang telah dikemukakan oleh para ulama dengan tujuan dan substansi yang sama, antara lain sebagai berikut. Menurut Ulama Al-Shafi iyah, ijarrah adalah:

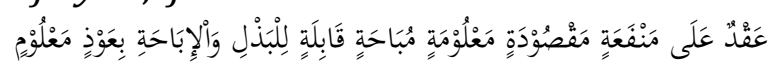

"Akad atas suatu kemanfaatan yang mengandung maksud tertentu dan mubah serta menerima pengganti atau kebolehan dengan pengganti tertentu". ${ }^{10}$

Menurut ulama Hanafiyah, ijarah ialah:

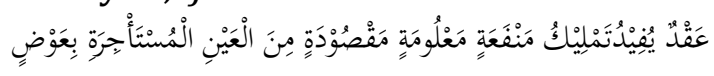

"Akad untuk membolehkan pemilikan manfaat yang diketahui dan disengaja dari suatu zat yang disewa dengan imbalan"11

Menurut ulama Malikiyah, ijārah ialah:

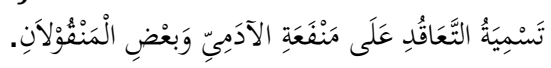

\footnotetext{
${ }^{8}$ Chairuman Pasaribu and Suhrawardi K. Lubi, Hukum Perjanjian Dalam Islam (Jakarta: Rajawali Pers, 1993).52

${ }^{9}$ Helmi Karim, Fiqih Muamalah, n.d.29

${ }^{10}$ Rachmat Syafei, Fiqih Muamalah, n.d.122

${ }^{11}$ Ibid.
} 
"Nama bagi akad-akad untuk kemanfaatan yang bersifat manusiawi dan untuk sebagian yang dapat dipindahkan"12

Dari beberapa definisi di atas dapat dipahami bahwa ijarah adalah menukarkan sesuatu dengan imbalan tertentu yang dalam terjemahan bahasa Indonesia disebut sewa menyewa atau upah mengupah. Sewa menyewa merupakan jual beli manfaat atas barang tertentu, sedangkan upah mengupah merupakan jual beli jasa atau tenaga atas perbuatan atau pekerjaan tertentu. ${ }^{13}$

Ijärah dalam bentuk sewa menyewa maupun dalam bentuk upah mengupah merupakan muamalah yang disyariatkan dalam Islam. Hukum asalnya menurut jumhur ulama adalah mubah atau boleh bila dilaksanakan sesuai dengan ketentuan yang ditetapkan oleh syara'. ${ }^{14}$ Berikut landasan hukum dibolehkannya ijarah yang terdapat didalam Al-Quran Surat Al-Qașas (28) ayat 26-27:

"Salah seorang dari kedua wanita itu berkata: "Ya bapakku ambillah ia sebagai orang yang bekerja (pada kita), karena Sesungguhnya orang yang paling baik yang kamu ambil untuk bekerja (pada kita) ialah orang yang kuat lagi dapat dipercaya". (26). berkatalah Dia (Syu'aib): "Sesungguhnya aku bermaksud menikahkan kamu dengan salah seorang dari kedua anakku ini, atas dasar bahwa kamu bekerja denganku delapan tahun dan jika kamu cukupkan sepuluh tahun Maka itu adalah (suatu kebaikan) dari kamu, Maka aku tidak hendak memberati kamu. dan kamu insya Allah akan mendapatiku termasuk orang- orang yang baik(27)." (al-Qașaṣ 28: 26-27) ${ }^{15}$

\footnotetext{
${ }^{12}$ Hendi Suhendi, Fiqh Muamalah (Jakarta: PT RajaGrafindo Persada, 2008). 114

${ }^{13}$ Syafei, Fiqih Muamalah. 125

${ }^{14}$ Abdul Rahman Ghazali, Fiqh Muamalat (Jakarta: Kencana, 2010).277

15 Departemen Agama RI, Al-Qur'an Dan Terjemahnya.388
} 


\section{Rukun Syarat Ijärah}

Menurut jumhur ulama, rukun ijarah ada empat, yaitu:

1. 'Aq id, yaitu mu'jir (orang yang menyewakan) dan musta'jir (orang yang menyewa).

2. Sighat, yaitu perbuatan yang menunjukkan terjadinya akad berupa ijab dan qabul.

3. Ujrah (uang sewa atau upah).

4. Manfaat, baik manfaat dari suatu barang yang disewa atau jasa dan tenaga dari orang yang bekerja. ${ }^{16}$

Syarat-syarat sewa-menyewa adalah sebagai berikut:

1. Manfaatnya diketahui, misalnya menempati rumah, menjahit pakaian, dan sebagainya. Karena ijarah seperti jual beli, dan jual beli disyaratkan barangnya harus diketahui.

2. Manfaatnya diperbolehkan. Jadi, tidak diperbolehkan penyewaan budak wanita untuk digauli, atau penyewaan wanita untuk bernyanyi, atau tanah untuk pembangunan gereja atau pabrik minuman keras.

3. Biaya sewa/ upahnya diketahui. ${ }^{17}$

Apabila ditinjau dari sifat akad ijarah yang mengikat kedua belah pihak atau tidak, terdapat perbedaan pendapat ulama menegenai hal tersebut. Ulama Hanafiyah berpendapat akad ijarah bersifat mengikat tetapi dapat dibatalkan secara sepihak apabila terdapat uzur dari salah satu pihak yang berakad. Adapun Jumhur ulama mengatakan bahwa akad ijarah bersifat mengikat kecuali ada cacat atau barang tidak bisa dimanfaatkan. Menurut Sayyid Sabiq, akad ijärah dapat menjadi batal dan berakhir bila ada hal-hal sebagai berikut:

1. Terjadinya cacat pada barang sewaan ketika ditangan penyewa

2. Rusaknya barang yang disewakan, seperti ambruknya rumah runtuhnya bangunan gedung

\footnotetext{
${ }^{16}$ Ibid.

${ }^{17}$ Ismail Nawawi, Ekonomi Islam- Teori, Sistem, Dan Aspek Hukum (Surabaya: CV. Putra Media Nusantara, 2009).186
} 
3. Rusaknya barang yang diupahkan, seperti bahan baju yang upahkan untuk dijahit.

4. Telah terpenuhinya manfaat yang diakadkan sesuai dengan masa yang telah ditentukan dan selesainya pekerjaan.

5. Menurut Hanafiyah salah satu pihak dari yang berakad boleh membatalkan akad ijarah jika ada kejadian-kejadian yang luar biasa, seperti terbakarnya gedung, tercurinya barang-barang dagangan dan kehabisan modal.

6. Menurut ulama Hanafiyah apabila ada udhur seperti rumah disita maka akad berakhir. Sedangkan jumhur ulama melihat bahwa udhur yang membatalkan ijärah itu apabila objeknya mengandung cacat atau manfaatnya hilang. ${ }^{18}$

Disamping itu, ulama Syafi'iyah dan Hanabilah juga berpendapat bahwa jika pekerjaan dilakukan oleh pihak pekerja yang disewa, ia tidak berhak mendapatkan upah apabila ada yang rusak di tangannya. Karena, ia tidak melakukan pekerjaan dengan baik. ${ }^{19}$

\section{Pengertian Jual Beli}

Secara bahasa, al-bay' artinya pertukaran secara mutlak. Kata al-bay' (jual) dan shira' (beli) pemakaiannya sama keduanya. Adapun secara syariat, jual beli adalah pertukaran harta dengan harta atas dasar keridhaan antara keduanya. Atau mengalihkan kepemilikan barang dengan kompensasi (pertukaran) berdasarkan cara yang dibenarkan syariat. ${ }^{20}$

Menurut Imam Ahmad, jual beli secara bahasa adalah muqabalatu shay'in bi shay'in yaitu suatu bentuk akad penyerahan sesuatu dengan sesuatu yang lain. Sedangkan menurut istilah adalah memiliki suatu harta dengan cara mengganti dengan izin syara', atau memiliki manfaatnya saja

\footnotetext{
${ }^{18}$ M Ali Hasan, Berbagai Macam Transaksi Dalam Islam (Fiqh Muamalat) Ed. 1 Cet. 2 (Jakarta: PT Raja Grafindo Persada, 2004).238

${ }^{19}$ Sayyid Sabiq, Fiqh Sunnah (Bandung: PT. Al-Ma'arif, 1987).309

${ }^{20}$ Abdul . Dkk Majid, Sulaiman bin Ahmad bin Yahya Al-Faifi. Terj, Mukhtashar Fiqih Sunnah Sayyid Sabiq (Solo: Aqwam, 2010).259
} 
yang diperbolehkan syara' dengan melalui pembayaran yang berupa uang. ${ }^{21}$

\section{Dasar Hukum Jual Beli}

1. Al-Qur'an

" Orang-orang yang Makan (mengambil) riba tidak dapat berdiri melainkan seperti berdirinya orang yang kemasukan syaitan lantaran (tekanan) penyakit gila. Keadaan mereka yang demikian itu, adalah disebabkan mereka berkata (berpendapat), Sesungguhnya jual beli itu sama dengan riba, Padahal Allah telah menghalalkan jual beli dan mengharamkan riba. orang-orang yang telah sampai kepadanya larangan dari Tuhannya, lalu terus berhenti (dari mengambil riba), Maka baginya apa yang telah diambilnya dahulu (sebelum datang larangan); dan urusannya (terserah) kepada Allah. orang yang kembali (mengambil riba), Maka orang itu adalah penghuni-penghuni neraka; mereka kekal di dalamnya. (QS. Al-Baqoroh :275) ${ }^{22}$

2. Hadis

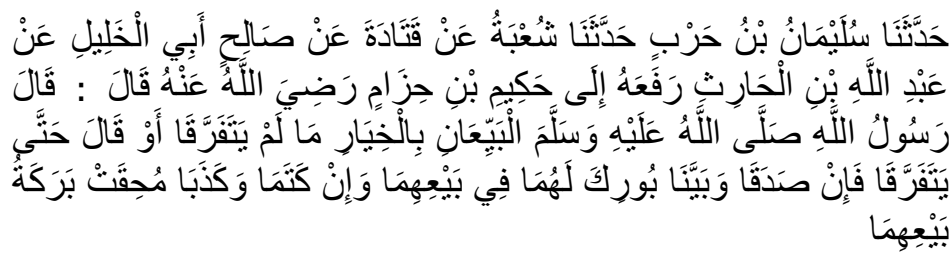

"Telah menceritakan kepada kami Sulaiman bin Harb telah menceritakan kepada kami Syu'bah dari Qatadah dari Shalih Abu AL Khalil dari 'Abdullah bin Al Harits yang dinisbatkannya kepada Hakim bin Hizam radliallahu 'anhu berkata; Rasulullah shallallahu 'alaihi wasallam bersabda: "Dua orang yang melakukan jual beli boleh melakukan khiyar (pilihan untuk melangsungkan atau membatalkan jual beli) selama keduanya belum berpisah", Atau sabda Beliau: "hingga keduanya berpisah. Jika keduanya jujur dan

${ }^{21}$ Imam Ahmad, Fathul Qorib (Surabaya: Nurul Huda, n.d.).30

${ }^{22}$ Departemen Agama RI, Al-Qur'an Dan Terjemahnya.47 
menampakkan dagangannya maka keduanya diberkahi dalam jual belinya dan bila menyembunyikan dan berdusta maka akan dimusnahkan keberkahan jual belinya". ${ }^{23}$

3. Ijma'

Kaum muslimin telah sepakat dari dahulu sampai sekarang tentang kebolehan hukum jual beli. Oleh karena itu hal ini merupakan bentuk ijma' umat, karena tidak ada seorang pun yang menentangnya. ${ }^{24}$

Dari kandungan ayat al-Quran di atas, hadis Nabi Saw dan ijma', para ulama mengatakan bahwa hukum asal jual beli adalah mubah atau jawaz (boleh) apabila terpenuhi syarat dan rukunnya. Tetapi pada situasi tertentu, hukum bisa berubah menjadi wajib, haram, mandub dan makruh. ${ }^{25}$

\section{Pengertian Teori Wakālah Bil Ujroh}

Secara bahasa kata al- wakalah atau al-wikalah berarti al-tafwidh penyerahan, pendelegasian, dan pemberian mandat, seperti perkataan: "aku serahkan urusanku kepada Allah swt. ${ }^{26}$ wakalah bil ujrah merupakan perikatan antara dua belah pihak pemberi kuasa (Muwakil) yang yang memberikan kuasanya kepada (wakil), di mana (wakil) mewakilkan untuk mengerjakan sesuatu dengan memberikan ujrah (fee/upah) kepada wakil yang yang mengerjakan tugasnya dan kewajiban bagi wakil untuk menjalankan tugas dari muwakil dengan sebaik-baiknya dan tidak boleh membatalkan secara sepihak.

Jadi bisa dikatakan akad wakalah bil ujrah akan melahirkan sumber kewajiban yang harus terpenuhi. ${ }^{27}$ Dalam

\footnotetext{
${ }^{23}$ Imam Bukhori, Kitab Bukhari, Hadist No. 1937(Lidwah Pustaka i-SoftwareKitab Sembilan Imam, 1937).

${ }^{24}$ Enang Hidayat, Fiqih Jual Beli (Bandung: PT. Remaja Rosdakarya, 2015).15

${ }^{25}$ Ibid. 16

${ }^{26}$ Abdul Rahman Ghazaly, Fiqih Muamalah (Jakarta: Kencana Prenada Media, 2010). 187

${ }^{27}$ Agus Ernawan and Dkk, Solusi Berasuransi, Lebih Indah Dengan Syariah Cet 1 (Bandung: PT. Karya Kita, 2019).187
} 
salah satu pihak tidak menunaikan kewajibannya atau jika terjadi perselisihan diantara para pihak, maka penyelesainnya dilakukan melalui Badan Arbitrase Syariah setelah tidak tercapai kesepakatan melalui musyawarah. ${ }^{28}$

Dasar hukum mengenai Wakalah Bil Ujrah QS Al Yusuf Ayat/12: 55:

"Berkata Yusuf: "Jadikanlah aku bendaharawan negara (Mesir); Sesungguhnya aku adalah orang yang pandai menjaga, lagi berpengetahuan". ${ }^{29}$

Dalam konteks ayat ini, Nabi Yusuf as. siap untuk menjadi wakil dan pengemban amanah "Federal Reserve" negeri Mesir. Dan siap menjalankan tugas sebagai bendahara yang amanah dan menurut suatu pendapat ditakwilkan, bahwa Nabi Yusuf as. pandai dalam hal menulis dan menghitung. ${ }^{30}$

\section{Praktek Pemesanan Makanan melalui Layanan Jasa Go- Food pada Aplikasi Go-Jek}

Go-Food adalah layanan jasa dalam bentuk melakukan pesan antar makanan yang telah dipilih oleh pelanggan sesuai pilihan menu dari restoran atau kedai yang terdapat pilihannya pada aplikasi Go-Jek, yang kemudian akan ditemukan seorang pengendara (driver) yang bersedia membelikan dan mengantarkan pesanan makanan oleh pelanggan tersebut. 31

Harga makanan dan jumlah upah yang harus dibayar oleh pelanggan pun telah ditotal dalam aplikasi tersebut, sebab semua harga dari setiap pilihanan makanan dari warung, restoran atau toko tertentu telah tertera harga setiap menu masing-masing, ${ }^{32}$ setiap penjual makanan yang bergabung dalam go-food telah mendaftarkan tokonya di kantor Go-Jek

\footnotetext{
${ }^{28}$ Suarni, "Analisis Penerapan Akad Wakalah Bil Ujroh Pada Produk Bringin Investama Syariah" (Skripsi UIN Alaudin Makassar, 2016).

${ }^{29}$ Departemen Agama RI, Al-Qur'an Dan Terjemahnya.242

${ }^{30}$ Suarni, "Analisis Penerapan Akad Wakalah Bil Ujroh Pada Produk Bringin Investama Syariah."48

${ }^{31}$ Go-Food, “Aplikasi Go-Jek," www.go-jek.com/.

${ }^{32}$ Ibid.
} 
dengan menggunakan aplikasi khusus yakni Go-Resto untuk mempermudah dalam menanggapi dan menerima pemesanan dari pelanggan. ${ }^{33}$

Sedangkan terkait jumlah upah yang berhak diberikan kepada pengendara (driver) ditentukan oleh jarak perkilometer antara lokasi toko atau warung menuju lokasi pelanggan yang melakukan pemesanan. Ketika pelanggan telah selesai melakukan pilihan menu, akan muncul harga dari jarak toko tersebut. ${ }^{34}$

Melihat dari penjelasan dan kronologi diatas, penulis menyimpulkan bahwasannya terdapat tiga pihak yang terlibat dalam terjadinya transaksi pemesanan makanan melalui GoFood, yakni pelanggan (konsumen), pengendara (driver) dan toko/kedai makanan.

Metode pembayaran transaksi pemesanan ini terdapat dua cara, yakni pembayaran dengan Go-Pay dan pembayaran Cash (uang tunai). Bentuk pembayaran secara tunai dapat dilakukan oleh pelanggan (pemesan) apabila driver telah selesai melakukan transaksi pembelian dan tiba di lokasi pengiriman tersebut. Sedangkan pembayaran melalui Go-Pay yakni dengan menggunakan sejumlah saldo uang yang terdapat pada dompet aplikasi Go-Jek milik setiap pelanggan. Go-Pay tidak hanya digunakan untuk Go-Food saja, pada umumnya dapat dilakukan untuk membayar seluruh transaksi pelanggan di aplikasi Go-Jek dengan lebih praktis dan banyak diskon atau promo. ${ }^{35}$

Mengingat misi utama aplikasi Go-Jek adalah untuk memberikan dampak sosial melalui teknologi, namun hal tersebut tidak luput dari adanya beberapa masalah yang pernah terjadi diantara beberapa pihak. Seperti yang pernah dialami oleh beberapa driver di Surabaya ketika secara tibatiba pelanggan yang menggunakan metode pembayaran tunai

\footnotetext{
${ }^{33}$ Google, "Playstore."

${ }^{34}$ Go-Food, "Aplikasi Go-Jek."

${ }^{35}$ Ibid.
} 
membatalkan pemesanan padahal makanan tersebut telah dibeli dan hendak sampai pada lokasi pelanggan, ia harus menanggung rugi karena pembayaran di restoran menggunakan uang miliknya. Kemudian yang sering terjadi apabila kerugiannya diatas seratus ribu rupiah, maka driver membawa makanan tersebut ke kantor Go-Jek Surabaya diurus untuk memperoleh uang ganti rugi, meskipun tidak bisa langsung cair dan menunggu hingga kurang lebih 24 jam, itupun uang yang bisa dicairkan hanya $80 \%$ dari total biaya pemesanan. Apabila dibawah 50 ribu rupiah, mereka merelakannya/mengikhlaskannya dan memakluminya sebagai resiko. ${ }^{36}$

Sebagaimana yang dikatakan oleh Nadia Tenggara, Head of Business Go-Food bahwasannya pihak Go-Jek memberikan kebijakan di setiap kota, yang memberikan kompensasi penggantian uang driver secara penuh asalkan kejadian tersebut benar-benar merupakan kesalahan dari pemesan, dan dari awal pihak Go-Jek selalu memberikan himbauan pada driver setiap kali ingin mengambil orderan/pesanan Go-Food untuk selalu memastikan pesanan ke pelanggan melalui telepon, apabila hal tersebut telah dilakukan dan ternyata pelanggan tiba-tiba menghilang maka hal tersebut diajukan klaim ke kantor Go-Jek. Bahkan agar hal tersebut tidak terulang lagi, pihak Go-Jek juga memberi sanksi tegas dengan melakukan suspend akun pengguna yang terlihat tidak wajar dalam melakukan pesanan. ${ }^{37}$

Bagi pelanggan, resiko yang pernah terjadi adalah tarif yang sewaktu-waktu bisa berubah. terutama pada harga makanan dan juga terdapat biaya tambahan untuk parkir. Terkadang menu yang dipilih oleh pelanggan terdapat perubahan harga dari pihak restoran karena harga pada

${ }^{36}$ Ahmad Rijal (Driver Go-Food Go-Jek di Kota Surabaya), wawancara, Surabaya, 22 Maret 2018.

37 “Order Fiktif Go-Food," accessed April 12, 2018, https://m.detik.com/inet/cyberlife/d-3641395/belajar-dari-kasus-order-fiktif-gofood. 
aplikasi hanya estimasi saja, seperti yang pernah dialami oleh seorang pelanggan Go-Food yang menyatakan bahwa ia pernah beberapa kali membeli makanan melalui aplikasi Go-Food, namun harga yang tertera pada daftar menu pada aplikasi tidak sesuai dengan harga yang dibeli oleh driver, yakni lebih mahal dari harga di menu aplikasi. Terkadang pihak driver segera memberikan kabar tersebut dan mengkonfirmasi lagi apakah pembelian dilanjutkan. Namun ada juga driver yang tidak mengkonfirmasi terlebih dahulu dan ketika telah sampai, ia menunjukkan nota pembeliannya. ${ }^{38}$

Terkait biaya parkir, sering dijumpai terutama pembelian yang dilakukan di mall atau restoran besar, pelanggan pun bisa memaklumi dan memberikan uang ganti tarifnya dengan tunai. ${ }^{39}$ Namun apabila terdapat biaya parkir yang tanpa disertai bukti kertas/struk, terkadang pelanggan enggan/berat untuk memberikan uang ganti parkir, sehingga biaya parkir ditanggung oleh driver, namun jika suatu restoran/ warung tertentu yang sudah umum memiliki tarif parkir pelanggan akan memaklumi. Saat ini terdapat juga mall/restoran yang memberikan gratis biaya parkir khusus bagi para driver online.$^{40}$

Selain terkait tarif yang berubah, masalah yang pernah dialami oleh pelanggan adalah makanan yang diterimanya mengalami kerusakan dalam bungkusnya, misalnya pemesanan nasi dengan bungkus kertas yang basah terkena air hujan di jalan, sehingga memberikan perubahan rasa pada makanan. Hal ini mendapat komplain dan pelanggan pun kecewa sebab driver tidak menjaganya dengan baik. ${ }^{41}$

\footnotetext{
38 Nurhayati (Dosen di Fakultas Syariah UIN Sunan Ampel Surabaya), wawancara, Surabaya, 01 Agustus 2018.

${ }^{39}$ Ibid.

${ }^{40}$ David Eko Cahyo (pelanggan go-food pada aplikasi go-jek), Wawancara, Surabaya, 14 Maret 2018.

${ }^{41}$ Rizky, 13 Maret 2018.
} 


\section{Analisis Hukum Islam terhadap Praktik Pemesanan Makanan melalui Layanan Jasa Go-Food pada Aplikasi Go- Jek di Kota Surabaya.}

Setelah penulis membuat analisis pada praktik pemesanan makanan melalui jasa Go-Food pada aplikasi Go-Jek di Kota Surabaya, selanjutnya penulis akan menganalisisnya dengan menggunakan hukum Islam. Bahwasanrya praktik pemesanan makanan melalui Go-Food ini adalah dengan akad ijarah yang termasuk kategori sewa jasa, sebagaimana pengertian ijarah adalah upah atas pemanfaatan suatu benda atau imbalan suatu kegiatan, atau upah karena melakukan sesuatu aktivitas. ${ }^{42}$ Bentuk aktifitas yang dilakukan oleh penyewa jasa (driver) disini adalah dalam bentuk mengambil pesanan makanan dan mengirimkannya yang telah dipilih dan dibayar oleh pelanggan melalui aplikasi Go-Food Go-Jek dengan saldo Go-Pay. Atau dengan jasa membelikan terlebih dahulu dengan uang milik driver atas pesanan makanan yang dipilih oleh pelanggan melalui aplikasi Go-Food Go-Jek dengan pembayaran tunai di akhir transaksi yang dibayarkan pada driver beserta upahnya.

Apabila ditinjau dari kelengkapan empat rukun ijarah sebagaimana yang ditetapkan oleh jumhur ulama ${ }^{43}$ adalah sebagai berikut:

1. Aqid, yaitu mu'jir (orang yang menyewakan) adalah pihak driver Go-Jek dan musta'jir (orang yang menyewa) adalah para pelanggan layanan GoFood.

2. Sighat, yaitu perbuatan yang menunjukkan terjadinya akad berupa ijab dan qabul. Bentuk ijabnya adalah kegiatan pelanggan yang menentukan pilihan pemesanannya dan persetujuannya atas harga dari setiap makanan yang menjadi pilihannya ditambah biaya tarif/upah untuk driver, mengisi alamat pengiriman beserta metode pembayaran dan dituntaskan dengan klik kata "order" pada

\footnotetext{
${ }^{42}$ Karim, Fiqih Muamalah.29

${ }^{43}$ Suhendi, Fiqh Muamalah. 117
} 
aplikasi layanan Go-Food. Sedangkan bentuk qabul adalah munculnya seorang driver yang menerima pesanan layanan tersebut dan mengkonfirmasi pada pelanggan.

3. Ujrah (uang sewa atau upah), adalah uang tarif driver yang telah ditentukan oleh aplikasi Go-Food sesuai jarak antara warung/restoran menuju lokasi pengiriman, yang bisa diberikan kepadanya oleh penyewa jasa (pelanggan) di awal akad dengan Go-Pay atau di akhir akad dengan pembayaran tunai.

4. Manfaat, disini adalah bentuk layanan driver untuk membelikan dan mengantar makanan yang telah dipesan oleh pelanggan.

Rukun ijarah di atas ditinjau berdasarkan syarat rukun ijarah yang dikemukakan oleh Imam Nawawi yang berupa syarat bentuk manfaatnya diketahui, manfaatnya diperbolehkan menurut syara' dan upahnya diketahui. ${ }^{44}$ Maka, rukun syarat ijarah dalam pemesanan makanan melalui layanan Go-Food tersebut telah terpenuhi syaratnya.

Syarat rukun berkaitan dengan 'aqid yang harus berakal dan mumayyiz (dapat membedakan yang haq dan batil) menurut Hanafiah. ${ }^{45}$ Maka kesesuaian aturan syara' dalam transaksi ini bisa dilihat dari ketentuan awal untuk menggunakan layanan Go-Food Go-Jek setiap pihak baik pelanggan maupun driver harus memiliki akun terlebih dahulu untuk mengisi kelengkapan dan kejelasan identitas masingmasing, dalam mengisi data tersebut diperlukan orang yang telah berakal dan mencapai batas umur tertentu. Seperti halnya driver yang harus memiliki SIM C yang minimal berusia 17 tahun. Terkait usia pelanggan tidak bisa dipastikan, namun tentang kecapakan dalam menggunakan teknologi cukup bisa dijadikan tolak ukur seseorang itu berakal dan mumayyiz, apabila diketahui terdapat anak kecil mumayyiz yang

\footnotetext{
${ }^{44}$ Nawawi, Ekonomi Islam- Teori, Sistem, Dan Aspek Hukum.186

${ }^{45}$ Syafei, Fiqih Muamalah. 125
} 
melakukan transaksi tersebut, maka hukumnya sah secara syar'i disertai izin dari walinya. ${ }^{46}$

Sighat ijab qabul pada akad ini dilakukan oleh pelanggan sebagai musta'jir melalui aplikasi Go-Jek layanan Go-Food yang menghubungkan dirinya dengan driver sebagai mu'jir. Hal ini dilakukan dengan sistem online, dikarenakan butuhnya melakukan akad ijarah untuk melakukan pembelian ini dengan lokasi yang cukup jauh dari lokasi pelanggan. Legalitas akad layanan ijarah dengan sistem aplikasi online dalam Go-Food ini sah menurut hukum syara', ditinjau dari tujuan utama layanan jasa pada Go-Food ini adalah misi sosial untuk memudahkan para pelanggan dalam memenuhi kebutuhannya, menciptakan lapangan kerja bagi para pengendara dan juga membuka pasar online bagi para penjual makanan di Surabaya. Layanan GoFood memberikan kemudahan bagi mereka dalam melakukan transaksi dengan mencantumkan semua pilihan restoran dan menu makanan disertai harga yang jelas, beserta kejelasan upah bagi driver. agar tidak terjadi kesalahfahaman dan perselisihan di antara mereka. Hal tersebut telah memenuhi prinsip jual beli yang terhindar dari tadlis dan ghoror dan juga sangat sesuai dengan aturan syara' yakni kualitas dan kuantitas barangnya jelas, sehingga cukup dengan pesanan maka hal ini secara syar'i, prinsip maqașid al-shari'ah, istihsan dan 'urf juga dibolehkan. Dalam disukursus fiqih, jaul beli model ini dikenal sebagai al-salam atau al-salaf, yaitu jual beli pesanan. Bahkan Ibnu Abbas, sahabat Rasulullah Saw, menyatakan bahwa turunnya ayat 283 surat al-Baqarah ini mengandung hukum jual beli pesanan yang ketentuan waktunya harus jelas. Alasan lainnya adalah sabda Rasulullah Saw yang berbunyi:

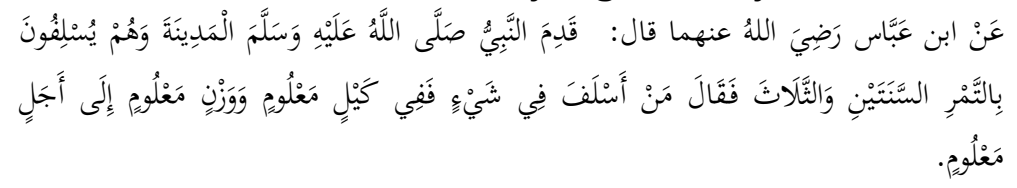

\footnotetext{
${ }^{46}$ Majid, Sulaiman bin Ahmad bin Yahya Al-Faifi. Terj, Mukhtashar Fiqih Sunnah Sayyid Sabiq.261
} 
"Dari Ibnu 'Abbas RA berkata: "Ketika Rasulullah shallallahu 'alaihi wasallam tiba di Madinah, mereka (penduduk Madinah) mempraktekan jual beli buahbuahan dengan sistim salaf, yaitu membayar dimuka dan diterima barangnya setelah kurun waktu dua atau tiga tahun kemudian, Maka Beliau bersabda: "Siapa yang mempraktekkan salaf dalam jual beli buah-buahan hendaklah dilakukannya dengan takaran yang diketahui dan timbangan yang diketahui, serta sampai waktu yang di ketahui" 47

Dapat disimpulkan bahwa akad ijarah ini terjadi antara pihak driver dengan pelanggan, sedangkan akad jual beli terjadi antara pelanggan dengan pihak penjual makanan/restoran. Kedua akad tersebut dapat dikategorikan pula menjadi akad wakalah bil ujroh, sebagaimana tindakan yang dilakukan oleh driver adalah mewakili pihak pelanggan untuk membeli suatu makanan dan memperoleh upah atas perwakilannya tersebut. Kemudian ditinjau dari rukun syarat wakalah bil ujroh, yang pertama adanya dua pihak yang berakad yakni antara pelanggan (muwakil) dengan driver (wakil), yang menjadi mahallul 'aqd (objek perikatan) disini adalah makanan, kemudian ijab qabul-nya terjadi dalam kesepakatan secara online antara keduanya yang berawal dari pelanggan memilih menu pesanan makanan hingga menekan tombol "pesan sekarang" yang kemudian terhubung dengan driver yang bersedia menerima pembelian pemesanan makanan tersebut melalui aplikasi Go-Jek. Akad wakalah ini termasuk jenis wakalah muqayyadah, karena pelanggan memberikan kriteria makanan tertentu yang telah dipilihnya pada aplikasi.

Terkait beberapa resiko yang terjadi pada praktik pemesanan makanan melalui jasa Go-Food, kecurangan dan penipuan sering dilakukan oleh pihak pelanggan/pemesan sehingga banyak driver yang menanggung kerugian. Para pelanggan yang melakukan kecurangan atau memutus akad

${ }^{47}$ Imam Bukhari, Kitab Bukhari Hadist No.2086, n.d. 
dengan pembatalan sepihak tanpa alasan yang jelas tersebut telah menyalahi aturan syariat. Terutama yang dilakukan dengan pembayaran secara tunai. Sebagaimana menurut Hanafiyah, bahwasannya salah satu pihak dari yang berakad boleh membatalkan akad ijarah jika ada kejadian-kejadian yang luar biasa, seperti terbakarnya gedung, tercurinya barangbarang dagangan dan kehabisan modal. ${ }^{48}$ Disamping itu, pihak Go-Jek sedikit memberikan bantuan kepada para driver yang menjadi korban kecurangan para pelanggan yang memutus akad dengan mengganti sejumlah uang $80 \%$ dari harga makanan yang dibelinya. ${ }^{49}$ Itu merupakan suatu kebijakan yang baik dari pihak Go-Jek.

Perihal perubahan harga makanan yang tidak sesuai dengan kesepakatan pada aplikasi, maka harus ditanggung oleh pihak driver apabila pelanggan merasa keberatan dengan perubahan harga tersebut, terkecuali pelanggan yang menerima kenaikan harga dengan rela dengan bukti nota yang diberikan olehnya. Begitu pula apabila terjadi kerusakan yang disebabkan kelalaian driver sehingga terjadi kerusakan hingga merubah esensi pada makanan yang dipesan oleh pelanggan, maka driver harus siap dengan segala resikonya apabila terdapat komplain dari pelanggan sebagai bentuk pertanggung jawabannya.

\section{Penutup}

Berdasarkan semua landasan teori terkait ijarah, jual beli dan akad wakalah bil ujroh yang digunakan untuk menganalisis hasil data lapangan yang telah peneliti peroleh, maka dapat disimpulkan bahwa Praktik Pemesanan makanan melalui Go-Food pada aplikasi Go-Jek menurut syariat Islam menggunakan akad ijärah. Aqid yakni mu'jir (orang yang menyewakan) adalah driver Go-Jek dan musta'jir (orang yang menyewa) adalah para pelanggan layanan GoFood. Sighat, yaitu

\footnotetext{
${ }^{48}$ M. Ali Hasan, Berbagai Macam Transaksi Dalam Islam (Fiqh Mu'amalat), n.d. 238

${ }^{49}$ Ahmad Rijal, Driver Go-Food Go-Jek, 22 Maret 2018.
} 
ijab dan qabul-nya terjadi pada sistem aplikasi online Go-Food Go-Jek yang dilakukan oleh pelanggan dengan driver. Ujrah (upah) tarif driver ditentukan oleh aplikasi Go-Food sesuai jarak antara warung/restoran menuju lokasi pengiriman, bisa diberikan kepadanya oleh penyewa jasa (pelanggan) di awal akad dengan Go-Pay atau di akhir akad dengan uang tunai.

Bentuk manfaatnya adalah layanan jasa driver dalam bentuk melakukan beli dan antar makanan yang telah dipilih oleh pelanggan dari beberapa restoran yang telah mendaftarkan jualan makanannya pada Go-Resto milik GoFood, sehingga dapat disebut pula sebagai akad wakalah bilujroh. Syarat rukun 'áqid yang harus berakal dan mumayyiz, setiap pihak baik pelanggan maupun driver harus memiliki akun terlebih dahulu untuk mengisi kelengkapan dan kejelasan identitas masing-masing. Resiko yang terjadi pada praktik pemesanan makanan melalui jasa Go-Food, diluar ketentuan umum dalam syarat praktik menggunakan layanan Go-Food, sebab kecurangan dan penipuan sering dilakukan oleh individu yang menyalahi aturan hukum dan kemanusiaan.

Sesuai dengan analisis hukum islam terkait teori akad ijarah dan teori jual beli terhadap praktik pemesanan makanan melalui layanan jasa Go-Food pada aplikasi Go-Jek di Surabaya secara umum telah terpenuhi syarat rukunnya dan sesuai dengan syariat Islam. Terkecuali apabila terdapat salah satu pihak yang menyalahi ketentuan hak dan kewajiban transaksi tersebut yang telah disepakati oleh mereka di awal akad sehingga merugikan salah satu pihak.

\section{Daftar Pustaka}

Ahmad, Imam. Fathul Qorib. Surabaya: Nurul Huda, n.d.

Asnawi. Teori Maslahat Dan Relevansinya Dengan Perundang Undangan Pidana Khusus Di Indonesia. Jakarta: Badan Litbang dan Diklat Kementrian Agama RI, 2010.

Bukhari, Imam. Kitab Bukhari Hadist No.2086, n.d.

Bukhori, Imam. Kitab Bukhari, Hadist No. 1937. Lidwah Pustaka 
i-Software-Kitab Sembilan Imam, 1937.

Departemen Agama RI. Al-Qur'an Dan Terjemahnya. Jakarta pusat: Pena, 2011.

Ernawan, Agus, and Dkk. Solusi Berasuransi, Lebih Indah Dengan Syariah Cet 1. Bandung: PT. Karya Kita, 2019.

Ghazali, Abdul Rahman. Fiqh Muamalat. Jakarta: Kencana, 2010. Ghazaly, Abdul Rahman. Fiqih Muamalah. Jakarta: Kencana Prenada Media, 2010.

Go-Food. “Aplikasi Go-Jek.” www.go-jek.com/.

Google. "Playstore."

Hasan, M. Ali. Berbagai Macam Transaksi Dalam Islam (Fiqh Mu'amalat), n.d.

Hasan, M Ali. Berbagai Macam Transaksi Dalam Islam (Fiqh Muamalat) Ed. 1 Cet. 2. Jakarta: PT Raja Grafindo Persada, 2004.

Hidayat, Enang. Fiqih Jual Beli. Bandung: PT. Remaja Rosdakarya, 2015.

Karim, Helmi. Fiqih Muamalah, n.d.

Majid, Sulaiman bin Ahmad bin Yahya Al-Faifi. Terj, Abdul . Dkk. Mukhtashar Fiqih Sunnah Sayyid Sabiq. Solo: Aqwam, 2010.

Mardani. Fiqh Ekonomi Syariah. Jakarta: Kencana, 2013.

Nawawi, Ismail. Ekonomi Islam- Teori, Sistem, Dan Aspek Hukum. Surabaya: CV. Putra Media Nusantara, 2009.

Pasaribu, Chairuman, and Suhrawardi K. Lubi. Hukum Perjanjian Dalam Islam. Jakarta: Rajawali Pers, 1993.

Sabiq, Sayyid. Fiqh Sunnah. Bandung: PT. Al-Ma'arif, 1987.

Sahroni, Oni, and Dkk. Maqashid Bisnis Dan Keuangan Islam. Jakarta: Rajawali Press, 2015.

Suarni. "Analisis Penerapan Akad Wakalah Bil Ujroh Pada Produk Bringin Investama Syariah.” Skripsi UIN Alaudin 
Praktik Pesan Makanan Melalui Go-Food Di Kota Surabaya Perspektif Hukum Islam ...

Makassar, 2016.

Suhendi, Hendi. Fiqh Muamalah. Jakarta: PT RajaGrafindo Persada, 2008.

Syafei, Rachmat. Fiqih Muamalah, n.d.

Syaltut, Mahmud. Al - Islam 'Aqidah Wa Shari'Ah. Kuwait: Daar al-Qalam, 1966.

"Order Fiktif Go-Food." Accessed April 12, 2018. https://m.detik.com/inet/cyberlife/d-3641395/belajardari-kasus-order-fiktif-go-food.

Ahmad Rijal (Driver Go-Food Go-Jek di Kota Surabaya), wawancara, Surabaya, 22 Maret 2018.

Ahmad Rijal, Driver Go-Food Go-Jek, 22 Maret 2018.

David Eko Cahyo (pelanggan go-food pada aplikasi go-jek), Wawancara, Surabaya, 14 Maret 2018

Nurhayati (Dosen di Fakultas Syariah UIN Sunan Ampel Surabaya), wawancara, Surabaya, 01 Agustus 2018. 